DOI: $10.13037 /$ ci.vol20n44.6069

\title{
Narrativas identitárías, autorismo e a canção popular no cinema: Clara e a música em Aquarius'
}

NARRATIVE IDENTITIES, AUTHORISM AND THE POPULAR SONG IN CINEMA: CLARA AND MUSIC IN AQUARIUS

\section{Rodrigo Carreiro ${ }^{2}$}

ORCID: https://orcid.org/0000-0003-3087-9557

(Universidade Federal de Pernambuco, Programa de Pós-Graduação em Comunicação. Recife PE, Brasil).

\section{Breno Alvarenga ${ }^{3}$}

ORCID: https://orcid.org/0000-0002-7185-0198

(Universidade Federal de Pernambuco, Programa de Pós-Graduação em Comunicação. Recife PE, Brasil).

Recebido em 16/05/2019. Aprovado em 13/08/2019.

\section{Resumo}

A partir de uma reflexão sobre a relação entre a música e os processos de construção de narrativas identitárias, este artigo procura investigar de que modo as canções populares podem ser capazes também de ajudar a construir narrativas identitárias ficcionais, em especial nos meios audiovisuais. Analisando o uso de canções para a construção da personagem Clara, no filme Aquarius (2016), procuraremos mostrar como a escuta dessas canções evidencia traços de sua personalidade, além de delinear também uma marca de autoria cinematográfica.

\section{Abstract}

Based on a reflection on the relationship between music and the processes of constructing narrative identities, this article seeks to investigate how popular songs may also be capable of helping to construct fictional narrative identities, especially in audiovisual media. Analyzing the use of songs for the construction of the character Clara, in the feature film Aquarius (2016), we try to show how the listening of these songs reveals traces of her personality, as well as delineating a brand of cinematographic authorship.

Palavras-Chave: Narrativa identitária. Canção popular. Trilha sonora.

Keywords: Narrative identities. Popular song. Soundtrack

1 O presente trabalho foi realizado com apoio da Coordenação de Aperfeiçoamento de Pessoal de Nível Superior (CAPES), dda Pró-Reitoria de Pesquisa (Propesq) da UFPE, e do Conselho Nacional de Desenvolvimento Científico e Tecnologico (CNPq). 


\section{Introdução}

Embora ocorra desde o início da história do cinema, o uso de canções populares na trilha sonora de filmes conquistou proeminência a partir dos anos 1960 (KALINAK, 2010; HUBBERT, 2014; PLATE, 2015), e ganhou expansão e diversidade ainda maiores nas três últimas décadas, graças ao uso engenhoso dado a elas por diretores populares como Quentin Tarantino e Danny Boyle. Aquarius (2016), filme de Kleber Mendonça Filho, oferece uma variedade incomum e interessante dessa tendência: soam durante a narrativa um total de 15 canções populares, sendo que 14 delas soam de forma diegética, ou seja, fazem parte do universo ficcional da trama, e são colocadas em cena e/ou escutadas pelos próprios personagens do filme.

O modo inusitado de uso da canção popular em Aquarius nos leva a questionar o papel conferido pelo diretor a essas canções na narrativa do filme, em particular quando percebemos claramente a relação afetiva entre elas e os personagens em cena. A partir da reflexão de Pablo Vila sobre música e narrativas identitárias (VILA, 2014), vamos buscar, neste artigo, investigar a relação entre essas canções em cena e as narrativas identitárias ficcionais, observando especialmente quais traços da personalidade da personagem Clara - a protagonista do filme, interpretada por Sônia Braga - se deixam transparecer nos seus processos de escuta musical. Em outras palavras: tentaremos estabelecer quais fragmentos da sua identidade são expostos a partir de sua relação com as canções, tornando-se afluentes do enredo ${ }^{2}$ ficcional. Levaremos em consideração, ainda, a tendência massiva do uso da canção popular como estratégia de autorismo ${ }^{3}$, conforme destacado por Claudia Gorbman (2007).

O artigo será desenvolvido em três seções. Na primeira, buscaremos contextualizar historicamente o uso de canções populares como trilha sonora de filmes, enfatizando o modo como essa modalidade musical tem não apenas ganhado mais proeminência, desde a emergência da geração New Hollywood, nos Estados Unidos, mas também enfatizando a relação estreita desta tendência com a noção de autoria vinculada ao poder dado ao diretor

2 Faz-se necessário observar que compreendemos a noção de enredo, aqui, como construção da trama ficcional, a partir de escolhas estilísticas e narrativas feitas pelo diretor, englobando elementos como ação, diálogos, narração e discurso.

${ }^{3}$ O autorismo, segundo Robert Stam (2003, p. 102), foi um movimento conceitual que passou a dominar a crítica e a teoria do cinema. Produto de uma formação cultural que incluía também cineclubes e periódicos especializados, o autorismo defendia a figura do diretor como o artista - o verdadeiro e único autor - por trás da realização do filme. Tal visão da cadeia produtiva cinematográfica, embora tenha sido desde então relativizados por pesquisadores e correntes teóricas diversas, permanece forte na maneira de compreender o cinema como arte. 
do filme para modular afetivamente a narrativa. Na segunda seção, discutiremos o modo como a canção popular é capaz de contribuir para a construção da narrativa identitária de personagens ficcionais, ancorada no conceito de memória (DENORA, 2004). Na terceira, analisaremos o uso de duas canções selecionadas e escutadas por Clara, demonstrando como essas cenas ajudam a construir a identidade e a personalidade da personagem.

\section{Cinema e canção popular}

O uso de canções populares na banda sonora de filmes remonta, como observa Julie Hubbert (2014, p. 291), aos primórdios do cinema. Nos primeiros anos da atividade, quando a linguagem audiovisual ainda estava em desenvolvimento e a tecnologia existente não permitia a reprodução sincrônica de imagem e som, músicos contratados providenciavam acompanhamento sonoro à exibição das imagens em movimento. Até meados da década de 1910, sequer era dada aos diretores e produtores dos filmes a possibilidade de selecionar quais músicas deveriam ser executadas; cada sala de exibição contratava profissionais para fazê-lo (dependendo do orçamento disponível, esse acompanhamento musical podia ser feito por um músico ou por uma orquestra completa). Havia, no comércio, livros de partituras para auxiliar os instrumentistas, mas estes tinham liberdade para selecionar composições que considerassem mais adequadas a cada filme (MIRANDA, 2011, p. 21). Nessa época, o uso de canções populares era bastante comum, a exemplo do ragtime Maple Leaf Rag, composto em 1899 por Scott Joplin - uma canção que, para muita gente, é praticamente sinônimo de cinema mudo 4 .

A partir do sucesso de $O$ Nascimento de uma nação (The birth of a nation, D.W. Griffith, 1915), um dos primeiros longas-metragens que teve música sinfônica composta especificamente para ele - embora usasse também temas populares -, a utilização de canções preexistentes praticamente desapareceu. Ao longo das quatro décadas seguintes, passaram a predominar no cinema composições sinfônicas influenciadas pelo estilo romântico do século XIX. Isso aconteceu, em parte, graças à chegada em massa, em Hollywood, de maestros imigrantes da Europa, como os austríacos Max Steiner e Erich Von Korngold, que fugiam da ascensão do nazismo e lá se estabeleceram. Esse estilo musical foi adotado em praticamente todos os países que produziam cinema, inclusive no Brasil (CARREIRO, 2018, p. 59).

${ }^{4}$ A expressão é desaconselhada, atualmente, por especialistas em história do cinema, por considerarem que os filmes sempre tiveram, desde sempre, acompanhamento sonoro, ainda que não sincronizada com a imagem. 
Quando as canções populares apareciam em filmes, muitas vezes ganhavam arranjos sinfônicos de sabor neorromântico.

Ao longo dos anos 1960, contudo, a inserção de canções populares na banda sonora dos filmes se transformou em tendência mundial. Mais uma vez, essa tendência nasceu nos EUA e se espalhou rapidamente por outros países. Isso aconteceu por muitas razões. Uma delas, destacada por Jeff Smith (1998), foi o crescimento da indústria fonográfica, que não demorou a criar vínculos com os estúdios de Hollywood; a inclusão de canções pop nos créditos de filmes - os temas da franquia 007 foram pioneiros nessa prática ajudava as gravadoras a venderem mais discos. Havia, também, uma questão diretamente ligada ao autorismo: os cineastas mais jovens, que tomavam conta de Hollywood em uma época de crise econômica, viam na canção popular uma forma de atrair a plateia para os cinemas. E essa não era a única razão pela qual eles gostavam de incluir canções pop nos filmes:

À nova geração, formada em universidades, estava sendo dada uma autonomia artística sem precedentes, e essa foi uma mudança que gerou a concepção de autor: os jovens cineastas queriam um controle criativo maior sobre todos os aspectos narrativos. [...] um dos elementos em que eles mais estavam interessados em controlar era a música (HUBBERT, 2014, p. 297).

Claudia Gorbman (2007) chama esses cineastas de "melômanos": diretores que enxergavam no uso da música uma marca autoral de estilo, uma grife a partir da qual seus nomes podiam ser identificados. Entre eles estavam Stanley Kubrick, Peter Bogdanovich, William Friedkin, Dennis Hopper, Mike Nichols e Martin Scorsese. Os três últimos investiram fundo nas canções pop como expressão sonora de autoria cinematográfica. Ao longo dos anos 1970 e 1980, o romantismo sinfônico se alternou com a canção popular, como formato musical predominante em Hollywood. A partir dos anos 1990, a prática que Kathryn Kalinak (2010) denomina de "compilation score" se tornou hegemônica. A essa altura, a trilha sonora de um filme passou a incluir, em média, entre 10 e 14 canções populares (HUBBERT, 2014, p. 302) - não por acaso, um número perfeitamente compatível com a quantidade de canções presentes em Aquarius, nosso estudo de caso.

A partir da década de 1990, o cineasta melômano - que às vezes contrata um supervisor musical para selecionar canções preexistentes, e em outras faz ele mesmo esse trabalho - se tornou figura comum no cinema ocidental, inclusive por razões comerciais, 
já que montar uma trilha sonora com canções preexistentes é mais barato do que pagar por música original. No Brasil, onde a música popular sempre encontrou espaço na banda sonora dos filmes - basta lembrar dos filmes tematizando o Carnaval, nos anos 1930, e das chanchadas produzidas nos estúdios Atlântida, entre os anos 1940-1960 -, a tendência do diretor-autor de índole melômana exerceu forte impacto no Cinema Novo. Cineastas como Glauber Rocha e Cacá Diegues usaram canções populares da Tropicália como estratégia criativa que era, simultaneamente, uma afirmação de autoria estilística e uma reivindicação biopolítica e identitária. Essa tendência continua forte até hoje.

\section{Narrativas identitárias e memória}

Em Aquarius, como já dissemos, 14 das 15 canções pertencem ao mundo diegético. Ao longo do enredo, elas são selecionadas para escuta por Clara, personagem principal do filme, uma viúva que mora em um dos últimos prédios antigos da praia de Boa Viagem, na orla do Recife, e resiste às investidas de uma construtora que deseja edificar um arranha-céu no lugar. Numa das primeiras cenas do longa, Clara e sua família se encontram no apartamento de Tia Lúcia, durante os anos 1980 - o mesmo lugar que ela luta para preservar, anos depois. É aniversário de Tia Lúcia e seus parentes e amigos the prestam homenagens relembrando fatos do seu passado.

Tia Lúcia agradece e em seu discurso lembra emocionada do seu marido falecido. As luzes baixam e a canção Toda Menina Baiana (1979), de Gilberto Gil, soa em cena, fazendo com que todos os personagens comecem a bailar e a cantar a canção. Observamos essa cena por alguns segundos, até que um fade faz com que aqueles personagens pouco a pouco sumam, dando lugar ao mesmo apartamento, porém agora vazio, claro pela luz do dia e com a decoração moderna. Uma Clara mais velha entra em cena, indicando uma passagem temporal, e destacando que a trama agora se desenrola no tempo contemporâneo. Interessante notar que a música de Gilberto Gil segue soando em cena, mesmo com essa passagem de tempo. Observa-se uma continuidade sonora mesmo com a quebra temporal, num movimento em que a música parece atrelada àquele espaço. $\mathrm{O}$ apartamento, mais de 30 anos depois, segue sendo o espaço onde reverbera a mesma canção, executada tanto no presente quanto no passado: enquanto a Clara atual se exercita ao som de Gilberto Gil, a antiga Clara bailava a mesma música, na mesma sala. Mesmo com o fade indicando a passagem do tempo, a persistência da música no cotidiano de Clara cria uma ponte entre passado e presente, inferindo sobre uma relação nostálgica de memória entre Clara e a canção. 
Boa parte dos poderes afetivos da música vem de sua co-presença com outros elementos - pessoas, eventos, cenas. Em alguns casos, o poder semiótico da música - aqui, sua capacidade emblemática - vem de sua presença condicional; ela simplesmente estava "lá no momento". Em tais casos, os significados específicos da música e sua ligação com certas circunstâncias simplesmente emergem da associação com o contexto no qual é ouvida. Em tais casos, o vínculo, ou articulação, que é feito - e com frequência biograficamente indelével - é inicialmente arbitrário, mas torna-se simbólico (e, portanto, evocatório) de sua relação com um contexto mais amplo de experiência, do momento em questão (DENORA, 2004, p. 66).

Tia DeNora indica, portanto, que parte do afeto atribuído a uma canção se desenvolve a partir da relação e atrelamento musical a pessoas e eventos do passado. Ouvir uma canção que carrega este tipo de significado é um movimento de reconexão com uma época, um momento, uma memória. Ainda segundo a autora, "a música pode ser usada como um dispositivo para o processo reflexivo de lembrar/construir quem se é, uma tecnologia para desenvolver o conto aparentemente contínuo de quem se é" (DENORA, 2004, p. 63).

Ao falar de memória, DeNora também se aproxima de uma relação que nos interessa: música e identidade. Nesta relação, a memória afetiva desempenharia papel fundamental na conexão entre passado e presente, sendo responsável pela impressão de continuidade da vida e seus eventos. O fato de Clara ouvir Toda Menina Baiana mais de 30 anos depois da primeira audição da canção não só a coloca em diálogo com memórias do passado, mas também informa ao espectador algo sobre a solidez de sua personalidade. Raphaël Nowak (2016) observa que a capacidade da música de atrelar-se a eventos do passado refere-se à noção de memórias mediadas, proposta por José Van Dijck (2007).

[a noção de] memórias mediadas se refere tanto a objetos concretos quanto a um conceito mental - um conceito que abrange aspectos da mente e do corpo, bem como da tecnologia e da cultura. No caso da música, isso significa que ouvir um determinado conteúdo afeta os indivíduos de uma forma que os faz 'reviver' alguns momentos específicos de seu passado (NOWAK, 2016, p. 76).

Podemos inferir que a canção, portanto, é um elemento mediador entre uma pessoa no presente e alguma memória de seu passado, num movimento em que a música é capaz de reconectar alguém a algum evento ou sentimento já vivido. Como inicialmente 
indicado, a música acaba por ser um elemento afetivo capaz de auxiliar as pessoas a ordenarem memórias e vivências em linhas de tempo, corroborando para a organização das experiências vividas. Tia DeNora afirma que "nesse sentido, o passado, quando evocado musicalmente, torna-se um recurso para uma movimentação reflexiva do presente para o futuro, uma produção momento a momento de agenciamento em tempo real" (2004, p. $66)$.

Uma música associada a algum evento passado, quando colocada em escuta no presente, faz com que o ouvinte relembre aquele tempo, compare-o ao momento atual e reflita sobre o percurso percorrido entre os dois períodos. Por isso, ela conclui que esse processo "serve também como um meio de colocar atores em contato com competências, lembrando-os de identidades conquistadas, o que, por sua vez, alimenta a projeção contínua de identidade do passado para o futuro" (DENORA, 2004, p. 66).

De uma perspectiva narrativa de construção de personagem, é possível compreender o uso da canção como uma ferramenta estilística selecionada pelo diretor e roteirista do filme, Kleber Mendonça Filho, para dar a Clara uma personalidade discernível: a música funciona como um elemento que simboliza o passado como referência importante de afeto e personalidade para Clara. De fato, é possível perceber que o uso da canção popular para delinear o arco dramático da personagem é recorrente no filme, já que outras 13 canções serão selecionadas e escutadas por Clara ao longo da projeção, enfatizando um padrão de nostalgia e memória como elemento fundamental para a construção da personalidade de Clara. Esse padrão simboliza aquilo que Tia DeNora chama de "identidade". Para a autora, "os materiais musicais fornecem termos e modelos para a elaboração de identidade própria - para a identificação de identidade" (DENORA, 2004, p. 68).

Pablo Vila, por sua vez, problematiza o termo, comentando sobre o aspecto efêmero, mutável e, principalmente, imaginado da concepção cotidiana de identidade. No entanto, ele não ignora essa relação e afirma que "parte da compreensão de nossa identidade (que é sempre imaginária) ocorreria quando nos submetemos ao prazer corporal da performance ou da escuta musical" (VILA, 2014, p. 35). O autor, porém, propõe um outro termo para se referir aos processos de construções identitárias:

[...] a maioria (mas não todas) as pessoas, para se entenderem como seres significativos, devem considerar suas vidas como algo mais do que uma série isolada de eventos, e é exatamente aí que as narrativas identitárias estão envolvidas - transformando eventos isolados em episódios ligados por um enredo. Como Somers (1992, p. 600) enfatiza, chegamos a ser quem somos (embora efêmeros, múltiplos e mutáveis) 
por nosso posicionamento (geralmente inconsciente) em narrativas sociais e redes de relações que raramente são criadas por nós mesmos (VILA, 2014, p. 37, grifo nosso).

Segundo Vila, é através das narrativas identitárias que as pessoas são capazes de organizar os eventos de suas vidas, dar-lhes significado, correlacioná-los. Por meio das linhas de tempo oferecidas pelas narrativas identitárias, é possível que um sujeito dê sentido ao que é vivido, tendo lampejos de quem se é e quem se tornou. Mas, afinal, qual seria o papel da música nessas narrativas? Pablo Vila acredita que também as canções constroem narrativas que podem ou não se atrelar às nossas narrativas identitárias.

Nesse sentido, penso que avaliamos, provisoriamente e situacionalmente, o que uma dada prática musical tem a nos oferecer em termos de interpelações em relação aos enredos básicos que estão sempre por trás das diferentes narrativas identitárias que construímos para entender as diversas posições subjetivas que acabamos por aceitar (através de um complicado processo de negociação) em nossa vida cotidiana. Assim, os enredos de nossas diversas narrativas, provisória e situacionalmente, são responsáveis pelas diferentes alianças que estabelecemos entre nossas diversas e imaginárias narrativas identitárias e as identidades imaginárias que diferentes práticas musicais tentam concretizar (VILA, 2014, p. 36).

De forma resumida, Vila acredita que as músicas traçam narrativas identitárias, através de diversos recursos: pela letra, pela performance do artista, pelas características acústicas, pelo que é dito sobre a música na mídia, por conversas do dia-a-dia que incluem a canção como tema, e assim por diante. Esses recursos podem interpelar as narrativas identitárias daqueles que escutam determinadas músicas - narrativas essas que são sempre situacionais e provisórias -, estabelecendo ou não processos identificatórios. Ou seja, tanto a música quanto as vivências daqueles que a escutam estão em processo permanente de negociação de identificações.

Neste sentido, localmente e provisoriamente, e em relação a uma performance musical específica e a uma abertura especial para o evento musical em questão (você nunca vai a um show ou ouve um CD ou uma faixa no iPod pelas mesmas razões), um esboço particular de um enredo correspondente a uma posição subjetiva peculiar (a questão étnica, por exemplo, mas sempre articulado com outras posições subjetivas e com os ecos de muitas mais por trás dessa articulação em particular) pode ser ativado (não sem modificações) quando articula-se (não sem negociações) com a interpelação étnica que, por exemplo, a música e a letra de uma canção oferecem (VILA, 2014, p. 53). 
Dessa forma, percebemos que nossas diversas narrativas identitárias são moldadas em torno de certos enredos. No exemplo acima, o autor explica como uma posição subjetiva, como a questão étnica, pode ser o enredo de algumas dessas narrativas identitárias. Uma canção, então, pode articular-se e interpelar essa posição subjetiva de um sujeito, traçando relações de identificação. E a questão étnica, evidentemente, é apenas uma das múltiplas conexões que podem funcionar como pontos de conexão entre as narrativas identitárias dos ouvintes e de uma canção (ou seja, tópicos sobre gênero, sexualidade, idade, classe social, nacionalidade e religião, entre outros temas, também são comentados pela música).

Até aqui, parece-nos mais clara a relação entre música e identidade, em que não se pode negar o papel da música como elemento cultural importante na construção dessas narrativas identitárias - inclusive em enredos ficcionais, como no caso de Clara. Se a música articula-se com processos identificatórios dos sujeitos, nos fazendo perceber quem somos (ou quem cremos ser) e localiza-nos temporariamente no fluxo da vida, busca-se compreender como os realizadores cinematográficos utilizam-se dela para também pontuar estes aspectos em seus personagens (revelando narrativas destes que são subjacentes à narrativa principal). Claudia Gorbman preocupa-se como uma questão semelhante:

Mais notavelmente, a naturalização do uso de canções populares em filmes mudou completamente as formas como nos relacionamos com enredos e personagens de filmes. Os universos de [Quentin] Tarantino e [Martin] Scorsese e dos irmãos [Joel e Ethan] Coen e David Lynch, ou o personagem de Jack Black em Alta Fidelidade e muitos outros personagens que conhecemos através do seu gosto musical, são exemplos de como os filmes estabelecem políticas de identidade e gosto através das formas particulares como os personagens se relacionam com as músicas (GORBMAN, 2014).

Como pontua a autora, questões como gosto e política dos personagens podem ser construídos pelos diretores e roteiristas através do relacionamento destes com as canções em cena. A música atua como elemento sonoro que dá pistas de narrativas identitárias desses personagens (afinal, posicionamento político é uma questão subjetiva que também pode ser interpelada por uma canção).

Em Aquarius, esse processo é bastante claro. Como já explicamos, o tema do filme retrata a questão da especulação imobiliária, e a narrativa nos apresenta à uma personagem e sua luta para tentar evitar que o prédio em que mora seja destruído. As 
canções que soam no filme pouco dizem ou acrescentam a esse tema. No entanto, a partir da relação estabelecida pela personagem com as músicas que escuta, as canções nos permitem acessar aspectos de caráter, personagem e ideologia de Clara, explicando e revelando as atitudes que ela toma, ao longo do filme, e que estão em consonância com algumas narrativas identitárias da personagem. Através das canções, somos capazes de entender aspectos da sua personalidade: a luta pela preservação do prédio é uma luta, de fato, para a preservação de uma geografia afetiva, da memória de um passado que Clara deseja preservar. Ao tomarmos dimensão da personalidade da personagem, passamos a compreender com mais clareza seus atos e falas ao longo do filme, num processo em que essas narrativas se tornam afluentes da narrativa principal, complexificando-a e nutrindo-a.

Na próxima seção, analisaremos duas das canções que soam em Aquarius, ambas colocadas em cena e escutadas pela personagem Clara. A partir da análise da relação da personagem com a música, tentaremos investigar quais narrativas identitárias podem ser estabelecidas para a personagem, sem deixar de atentar para a relação dos atos e da personalidade de Clara para com a narrativa principal.

\section{Duas canções}

Em uma das cenas do primeiro capítulo do filme, Clara recebe de uma construtora a proposta de compra do seu apartamento: a intenção é substituir o prédio da personagem por um edifício maior e mais moderno. Na cena posterior, sozinha, com o envelope em mãos e em frente ao edifício, ela rasga a proposta recebida. Em seguida, entra no carro do sobrinho Tomás (Pedro Queiroz). Clara questiona se ele foi capaz de gravar todas as músicas que havia lhe pedido, o que ele confirma: "Estão aqui no pen drive". Após conversarem um pouco mais sobre as músicas gravadas, Clara procura por alguma específica no rádio do carro: “Ah! Aí, ó. Ouve isso". Juntos e em silêncio, passam a ouvir com atenção a música Um jeito estúpido de te amar (Roberto Carlos, 1976), na voz de Maria Bethânia: Eu sei que eu tenho um jeito/Meio estúpido de ser/E de dizer coisas que podem magoar e te ofender/Mas cada um tem o seu jeito.

"Engraçado", comenta Tomás. Clara, abaixando o volume da música, insiste para que ele desenvolva o pensamento. "Estou meio alegrinho hoje", continua ele. A música torna-se um gatilho para que Tomás confidencie a Clara a chegada de uma garota do Rio de Janeiro que vem à sua visita. Tomás segue contando como conheceu a garota e suas 
expectativas para o encontro, o que diverte a tia. Olhando para a janela do carro reflexiva, Clara parece ter uma ideia: "Olha, faz uma coisa: toca Maria Bethânia para ela. Mostra que tu é intenso!”. Tomás ri e concorda: “Tudo bem”. Voltamos a escutar a canção vinda do rádio: Palavras são palavras/E a gente nem percebe o que disse sem querer/E o que deixou pra depois/Mais o importante é perceber/Que a nossa vida em comum/Depende só e unicamente de nós dois.

O que podemos inferir da personagem Clara a partir da sua relação com essa música? O que os gestos, comentários e reações à canção revelam da sua personalidade? Qual a relação desta cena com o tema principal do filme? O primeiro ponto que queremos explorar é o uso da palavra "intenso". Afinal, o que ouvir a canção na voz de Maria Bethânia tem a ver com intensidade? Em uma apresentação em Curitiba, no ano de 2011, Bethânia fez uma declaração que pode nos dar algumas pistas:

Eu gosto de emprestar a minha vida, a minha voz, às histórias e às personagens que os autores nos revelam. Eu sei que ler, ouvir, dizer poesia hoje, neste tempo de tanto desapego, tanta correria, é uma tarefa quixotesca, é como provocar e ofender o mundo, pois vivemos como se não coubesse mais o silêncio, as delicadezas. Isso me comove e me atrai (BETHÂNIA in FORIN JR., 2016).

No trecho acima, percebemos a tendência da artista de usar a voz e a performance ${ }^{5}$ como signos de poesias e sentimentos. Ela acentua na sua fala o poder e a força das delicadezas, comentando como isso a "comove" e a "atrai". A sua performance no palco chama a atenção pela carga emocional despertada e a união de elementos como a voz, a música, a poesia, a dança e o gesto. Marlon de Souza Silva pesquisou a carreira de Bethânia de 1965 a 1978. Segundo ele, das 271 músicas gravadas por ela no período, 128 tinham como tema "o amor, com seus desencontros, saudades, dores, tristezas, abandonos" (SILVA, 2010, p. 90). Para o pesquisador, a carga violenta das letras das canções permitia a Bethânia uma entrega performática e intensa nos palcos.

O romantismo em Bethânia está intimamente ligado à dramaticidade que estas canções possuem. Isso foi perceptível em sua relação com a bossa nova, na qual ela sentia falta da dramaticidade dos sambas antigos. Esta dramaticidade, creio que se relaciona com o palco, com

${ }^{5}$ Aqui, entendemos performance como um conjunto indissociável de signos auditivos e visuais, em que ela, segundo Paul Zumthor, “... é uma realização poética plena: as palavras são tomadas num conjunto gestual, sonoro, circunstancial tão coerente (em princípio) que, mesmo se se distinguem mal palavras e frases, esse conjunto como tal faz sentido" (ZUMTHOR, 2005, p. 87). Ou seja, em Maria Bethânia, elementos como a voz, o gesto, a dança, as luzes, o figurino, entre outros, tornam-se elementos importantes da performance. 
a interpretação. Este tipo de canção permitiria à Bethânia não apenas cantar, mas interpretar. (SILVA, 2010, p. 91).

O fato de Bethânia não só cantar as músicas, mas também interpretá-las em suas performances, evidencia o caráter intenso da artista. Ou seja, Clara infere que a escuta de Bethânia, indicada ao sobrinho, vai sugerir à garota que ele está conhecendo um nível de entrega e romantismo equivalentes àqueles demonstrados pela performance da cantora, como se aquele que ouvisse Bethânia pudesse sentir e viver o amor da mesma forma que ela, com intensidade.

Reconhecer-se na letra de uma canção, e nas performances de um cantor, pode ser uma ferramenta para os ouvintes reverem e repensarem aspectos de suas vidas. Traça-se um movimento de cumplicidade entre artista e fã, onde este que escuta sente-se representado e compreendido por aquele que canta. A letra de Um jeito estúpido de te amar reflete a intensidade defendida por Clara. A narrativa do filme não nos dá muitas referências de como teria sido o amor vivido entre Clara e seu falecido marido, mas duas cenas revelam nuances dessa relação. Na primeira, Clara tenta explicar para seus filhos a razão pela qual não quer vender seu apartamento. Durante a discussão, a filha Ana Paula diz: "Papai não está mais aqui...", sugerindo que ele saberia lidar melhor com aquela situação. Clara fecha os olhos, canta uma canção de Paulinho da Viola (a letra relata o comportamento de pessoas com "nervos de aço", dando a entender que Ana Paula seria este tipo de pessoa), e então lhe responde: “Ana, minha filha, a viúva do seu pai aqui sou eu, não é você não, viu? Difícil, né?”. E seus olhos se enchem de lágrimas. Nota-se que Clara ainda ama, mesmo que o alvo desse amor não esteja mais ali.

$\mathrm{Na}$ segunda cena, Clara visita o cemitério. Chegando próxima à sepultura do marido, ela abre a bolsa e retira um caderno vermelho. "Eu escrevi umas coisas, sabe, pra você. Mais fácil”. Coloca os óculos de grau, vasculha as páginas em busca do trecho correto e encara a sepultura. Desistindo de falar, fecha o caderno e guarda-o novamente na bolsa. Deposita no jazigo as flores que trouxe, recolhe os galhos secos que ali estavam e virando-se, vai embora. Essa cena, em especial, relaciona-se de forma interessante com a última estrofe de Um jeito estúpido de te amar: Palavras são palavras/E a gente nem percebe o que disse sem querer/E o que deixou pra depois/Mais o importante é perceber/ Que a nossa vida em comum/Depende só e unicamente de nós dois. Tanto a letra da canção quanto a atitude de Clara no cemitério parecem concordar com a debilidade das palavras para descrever o que foi vivido entre dois amantes. A canção evoca algo de que a linguagem não dá conta. 
[...] as canções permitem tornar os sentimentos inteligíveis, dar-lhes um nome, relacioná-los aos modos com os quais os sujeitos vinculam-se no afetivo-erótico em dado tempo e as consequências sentimentais dessas conexões; e, por sua vez, como performam as modalidades de emoções que afetam os laços afetivos (SPATARO, 2016, p. 76).

Uma segunda cena que nos interessa é a cena em que Clara escuta a canção O quintal do vizinho ${ }^{6}$, gravada por Roberto Carlos em 1975. Após ir a uma festa com amigas, Clara entra no carro de um homem que conhecera no recinto. Dentro do automóvel, começam a se beijar, até que ele toca os seios dela e percebe a ausência de um deles. A situação causa constrangimento. O homem se afasta, em desistência. Clara vai para casa de táxi, sozinha. Observa o seu prédio e então o prédio ao lado. Este segundo é um edifício alto, moderno, de varandas largas. Um grande véu branco indica que está em reforma. Dentro de casa, explora sua coleção de vinis e escolhe um disco. O trecho que ouvimos tem essa letra: Eu hoje acordei pensando/Num sonho que eu tive a noite/Sentei-me na cama para pensar/No sonho que eu tive/No sonho que eu tive/No sonho que eu tive/Fiquei tanto tempo pensando/Em tudo que estive sonhando/Que por um momento/Pensei ser verdade.

Clara cruza os braços, fecha os olhos e deixa o corpo balançar ao ritmo da música. Cada frase é ouvida com atenção. A música a acalma, o sorriso aumenta. Se na cena anterior acompanhamos o constrangimento amoroso da personagem, e então a observamos preocupada com o futuro do edifício, agora a vemos alcançando um estado de paz. Notamos que Clara utiliza a música como instrumento de regulação de suas emoções.

Tia DeNora (2004) percebe este mesmo tipo de utilização da música em entrevistados dentro de sua pesquisa (DENORA, 2004, p. 16). Ela sugere que esse movimento é consciente: as pessoas sabem que certas músicas animam, trazem bons sentimentos. DeNora explica que uma série de fatores podem estar envolvidos: a letra, as memórias e associações envolvidas, o local e circunstância da escuta, entre outros.

A música é ativa na vida social, tem "efeitos" portanto, porque oferece materiais específicos com os quais os atores podem contar com quando se envolvem no trabalho de organizar a vida social. A música é um recurso - fornece recursos - para a construção de mundo. (DENORA, 2004, p. 44).

${ }^{6}$ Os compositores da canção são Erasmo Esteves e José Alejandro Losi. 
Em outro trecho da canção, Clara dança ${ }^{7}$ pela sala, enquanto a letra da música narra um sonho: Sonhei que entrei no quintal do vizinho/E plantei uma flor/No dia seguinte ele estava sorrindo/Dizendo que a primavera chegou. A canção sugere um ambiente de harmonia entre vizinhos amigos. Esse trecho da letra conecta a canção ao tema principal do filme, visto que todos os vizinhos do prédio já abandonaram seus apartamentos e aguardam apenas a venda da parte de Clara para que o novo empreendimento ocupe o terreno. Além da construtora, ela também sofre a pressão destes vizinhos (um deles chega a chamá-la de egoísta ao encontrá-la na praia).

Nota-se que o processo de identificação de Clara com a música (para além do que lhe provoca emocionalmente) nos dá pistas de uma certa concordância dela com o eu-lírico sobre como se daria uma relação ideal entre vizinhos. A maneira como sorri enquanto canta nos faz crer que ela enxerga a beleza de se plantar uma flor no quintal alheio; the traz alegria considerar este tipo de relação tão singela e afetuosa. Esta percepção choca quando comparada com as relações desenvolvidas por ela e seus vizinhos no presente: relações de frieza, desacertos e distanciamentos.

\section{Considerações finais}

A relação entre música, autorismo e identidade tem se tornado, cada vez mais, um foco de interesse para investigações acadêmicas no campo dos estudos de som e música. Os pesquisadores têm percebido como é forte a importância da canção popular na percepção da passagem do tempo, nas transformações externas e internas dos sujeitos, na construção de personalidades de personagens, no estabelecimento de marcas de autoria. Ao mesmo tempo, na área da criação audiovisual, roteiristas e diretores têm compreendido a música como elemento que auxilia o processo narrativo de comunicar ao espectador aspectos da vida interior dos personagens, sem a necessidade de verbalizar esses aspectos em diálogos e narrações over.

O conceito de narrativas identitárias possui um papel importante nesses processos, pois valoriza a música como instrumento construtor de personalidades individuais, providenciando coesão e organização a acontecimentos da vida cotidiana que, de outra forma, permaneceriam dispersos e desconexos: "Na seleção dos acontecimentos de uma

\footnotetext{
${ }^{7}$ Simon Frith, em Perfoming Rites (1996), comenta sobre a capacidade de ouvir a música a partir da dança: "o que sentimos sobre uma música é o que ela significa; assim como os músicos, nós não temos tempo para interpretar primeiro os sons para então reagir a eles. Isso retoma o ponto de Richard Waterman: a maneira ideal de ouvir música é dançando, mesmo que apenas na sua cabeça” (FRITH, 1996, p. 139).
} 
vida estão incluídas as relações que estabelecemos entre nossas tramas e as múltiplas interpelações e práticas culturais que a cultura popular em geral e a música em particular nos oferecem para a identificação" (VILA, 2014, p. 61). Canções populares, portanto, são capazes de nos oferecer material afetivo para ser utilizado em processos identificatórios, ajudando-nos a organizar as múltiplas narrativas identitárias que vivenciamos, no cotidiano ou em universos ficcionais.

Assim, a análise do uso de algumas canções populares no enredo de Aquarius demonstra como a música pode fornecer a personagens da fiç̧ão uma organização afetiva semelhante ao que ocorre no mundo real. A música também ajuda os cineastas a comunicar afetos e sentimentos dos seres ficcionais aos espectadores, uma prática que amplia o potencial empático do cinema. Por fim, vimos também como a canção popular pode se transformar em marca autoral de estilo para muitos diretores.

\section{Referências}

CARREIRO, Rodrigo. "A história do som dos filmes". In: $O$ som do filme: uma introdução. (org. Rodrigo Carreiro), pp. 35-86. Curitiba: Editora da UFPR/Editora da UFPE, 2018.

DENORA, Tia. Music in everyday life. Cambridge: Cambridge University Press, 2004.

FORIN JR., Renato “ "Lirismo e construção rapsódicana performance de Maria Bethânia”. Estação literária, v. 15, pp. 220-236, jan. 2016.

FRITH, Simon. Performing rites: evaluating popular music. Oxford: Oxford University Press, 1996.

GORBMAN, Claudia. "Professor Emeritus" [website]. University of Washington Tacoma, 2014. Disponível em: http://directory.tacoma.uw.edu/employee/gorbman. Acesso em: 3 abr. 2019.

HUBBERT, Julie. "The compilation soundtrack from the 1960s to the present". In: The Oxford Handbook of film music (org, David Neumeyer), pp. 291-318. New York: Oxford University Press, 2013.

KALINAK, Kathryn. Film music: a very short introduction. New York: Oxford University Press, 2010. 
MIRANDA, Suzana Reck. "A clássica música das telas: o uso e a formação do tradicional estilo sinfônico". Ciberlegenda, v. 1, n. 24, pp. 19-28, 2011.

NOWAK, Raphaël. Consuming music in the digital era: technologies, roles and everyday life. London: Palgrave Macmillan, 2016.

PLATE, Nathan. Postwar Hollywood, 1947-1967. Sound: dialogue, music, and effects (org. Kathryn Kalinak), pp. 59-82. New Brunswick: Rutgers University Press, 2015.

Practices". Music and youth culture in Latin America. New York: Oxford University Press, 2014.

SILVA, Marlon de Souza. No meu canto trago tudo o que vivi: a tradição e o popular em Maria Bethânia. Dissertação (Mestrado), Universidade Federal de São João Del Rei, 2010.

SPATARO, Carolina. "Esa canción cuenta mi historia de amor: mujeres, música romántica y procesamiento social de las emociones". Canção romântica: intimidade, mediação e identidade na América Latina (org. Martha Tupinambá de Ulhôa, Simone Luci Pereira), pp. 71-94. Rio de Janeiro: Letra e Imagem, 2016.

STAM, Robert. Introdução à teoria do cinema. Campinas: Papirus, 2003.

VAN DIJCK, José. Mediated memories in the digital age. Palo Alto: Stanford University Press, 2007.

VILA, Pablo. Narrative Identities and Popular Music: Linguistic Discourses and Social

Practices. In: Music and Youth Culture in Latin America. Oxford: Oxford University Press, 2014.

ZUMTHOR, Paul. Escritura e Nomadismo. Cotia: Ateliê editorial, 2005.

${ }^{2}$ Doutor e Mestre em Comunicação (Cinema) pela Universidade Federal de Pernambuco. É jornalista formado pela Universidade Católica de Pernambuco. Realizou estágio pós-doutoral na Universidade Federal Fluminense (UFF), com bolsa da Capes. Professor do Programa de Pos-Graduação em Comunicação e do Bacharelado em Cinema e Audiovisual da UFPE. E-mail: rcarreiro@gmail.com. 
${ }^{3}$ Mestrando em Comunicação na Universidade Federal de Pernambuco, com bolsa do CNPq. É graduado em Publicidade pela Universidade Federal de Minas Gerais. E-mail: brenomalvarenga@gmail.com. 